\title{
STRATEGI BERCERITA CERITA SEJARAH ${ }^{1}$ ]
}

\author{
Tadkiroatun Musfiroh
}

\begin{abstract}
Abstrak
Sejarah memiliki bahan dasar cerita. Cerita sejarah merupakan cerita faktual yang bernilai kebenaran tinggi. Sejarah yang disajikan dalam bentuk cerita memiliki efektivitas yang sulit ditandingi oleh metode lain. Bercerita sejarah memerlukan strategi. Strategi dilakukan dalam tiga tahap, yakni tahap persiapan, penyajian, dan evaluasi. Pengemasan sejarah dalam bentuk cerita dapat menjadi alternatif pembelajaran karena sejarah memiliki materi beragam yang mampu menyedot perhatian anak didik. Cerita sejarah juga mampu merangsang minat baca peserta didik.
\end{abstract}

\section{Kata kunci: $\quad$ Sejarah, Metode Bercerita}

1) Tulisan ini diadaptasi dari makalah yang disampaikan dalam Seminar Nasional "Mendidik Anak dengan Sejarah, diselenggarakan oleh Prodi Pendidikan Sejarah IKIP PGRI Madiun, 20 April 2008.

Tadkiroatun Musfiroh adalah Dosen PBSI FBS UNY, Anggota Pusat Studi PAUD Lemlit UNY. 


\section{Pendahuluan}

Wawancara Tukul Arwana dengan Mirna (sales sex-shop) dan dr. Boyke, tanggal 8 April 2008 menggugah saya untuk mengubah paradigma berpikir mengenai cerita. Apa yang dimaksud dengan cerita, bukan hanya cerita seperti yang kita batasi sekarang. Cerita memiliki dunia yang sama luas dengan dunia itu sendiri. Apa pun yang ada di dunia ini tidak lepas dari cerita. Bahkan, hal yang diceritakan oleh dr. Boyke dan Mirna pun berwujud cerita yang diceritakan. Anak-anak menikmati cerita yang belum saatnya mereka nikmati dan cerita tersebut patut menjadi renungan semua pihak. Kita menjadi sadar, bahwa ternyata cerita memiliki dua sisi yang bertentangan. Satu sisi dia mengisi daftar metode mendidik yang menyenangkan, satu sisi lain dia mengisi daftar perusak karakter manusia (dari anak-anak, remaja, hingga orang dewasa).

Fenomena "Ayat-ayat Cinta" juga menarik diceritakan. Cerita fiksi (dalam konteks kesastraan) tersebut, berhasil menyentuh emosi banyak orang, tak terkecuali BJ. Habibie, SBY dan JK. TVOne menyitirnya menjadi sebuah anekdot, bahwa "Ayat-ayat Cinta" lebih menyentuh hati SBY-JK dibandingkan dengan cerita riil tentang gizi buruk, antrean minyak dan gas, serta cerita bencana alam. Apa pasalnya? Kuncinya adalah, cerita fiksi yang terolah dengan baik lebih mampu menyentuh emosi penik- matnya daripada fakta yang relatif kurang terolah dan terkesan datar.

Sejarah, sebagai sebuah fenomena, memiliki bahan dasar cerita, suatu rangkaian fakta yang terjadi di masa lalu dan menjalin membentuk cerita. Dengan demikian, sejarah merupakan cerita faktual (bukan fakta cerita) yang bernilai kebenaran tinggi. Meskipun muncul berbagai varian, yang konon menunggangi nilai kebenaran sejarah, hal yang patut dicatat adalah bagaimana kita harus menjaga kebersihan fakta dalam sejarah dan mengemas unsur peristiwa sehingga menjalin membentuk plot yang kenyal.

Dunia dimulai dengan cerita (Adam dan Hawa) dan berakhir dengan cerita (Kiamat). Permulaan dan akhir kehidupan manusia disi, diwarnai, serta dijelaskan melalui cerita. Baik buruk kehidupan ini pun disampaikan melalui cerita (gosip). Cerita benar-benar objek dan cara yang lekat dalam kehidupan manusia. Oleh karena itu, jalan terbaik adalah belajar membuat cerita yang lengkap secara intrinsik dan memanfaatkannya untuk tujuan yang baik. Perlu kita ingat kata-kata Winston Churchill, bahwa satusatunya hal yang kita pelajari dari sejarah adalah bahwa kita tidak benar-benar belajar darinya.

\section{Cerita Sejarah}

"Kesaktian" cerita sebagai
sarana penyampai pesan dengan
berbagai tujuan (mendidik, mem-


pengaruhi, bahkan merusak pola pikir) diakui oleh berbagai pihak. Salah satunya adalah disertasi Heather Forest dari Antioch University tahun 2007. Disertasi berjudul Inside Story: An Arts-Based Exploration of the Creative Process of The Storyteller as Leader menunjukkan bahwa cerita mampu memicu perubahan sosial. Bercerita memiliki kaitan dengan kemampuan berpikir kreatif melalui kekuatan cerita dan metafora (untuk menyampaikan ide-ide). Bercerita dapat menjadi suatu iluminasi, sebagai media untuk mengilhami perdamaian, keadilan, dan perubahan sosial yang positif.

Sejarah terkait erat dengan cerita. Sejarah adalah salah satu bahan cerita, dan cerita adalah salah satu cara menyajikan sejarah. Sebagian orang, bahkan, mendudukkan keduanya sebagai definisi belah dua, yakni bahwa sejarah adalah cerita yang dapat dipertanggungjawabkan kebenarannya. Cerita adalah sejarah yang perlu dipertanyakan kebenarannya. Cerita tidak lahir dari kekosongan budaya, dan sejarah adalah pengisi kebudayaan itu. Hal ini menunjukkan bahwa berbicara tentang sejarah, berbicara juga tentang cerita dan bercerita. Demikian pula sebaliknya.

Manusia tidak hidup dengan masa lalu, tetapi belajar dan berkembang/hancur oleh perilaku masa lalu. Sejarah menjadi tonggak kebenaran masa lalu yang dipancangkan sepanjang masa untuk menjaga plotnya agar tidak bergeser dari realitas sesungguhnya. Walaupun banyak pihak menafsirkan se- jarah sebagai tafsir peristiwa (sehingga banyak muncul versi sejarah), masih banyak orang yang percaya (dan berharap) agar sejarah menjadi rekaman peristiwa yang benar-benar nyata. Meskipun demikian, yang terpenting dari itu semua adalah bagaimana memanfaatkan sejarah sebagai bahan baku cerita yang appropriate, dan menyebarluaskan sejarah sebagai pelajaran penting kehidupan.

Sejarah hanya akan mendiami file cerita awam, apabila hanya berisi peristiwa yang ditumpuk atau interpretasi peristiwa yang dipaparkan. Alih-alih menjadi bahan renungan, sejarah semacam ini akan cepat dilupakan dan terasa tipis kadar kebermanfaatnya. Sebaliknya, sejarah akan menjadi sumber program yang menginfeksi pengetahuan dan nurani anak didik apabila mampu menyuguhkan komponen cerita secara liat. Cerita sejarah yang berkualitas disajikan dengan komponen tema, penokohan, plot, latar, latar belakang cerita, dan detil. Cerita sejarah yang demikian, akan menjadi mata bagi banyak orang (terutama anak didik) untuk belajar melihat kaitan masa lalu dan masa sekarang, dan pada muaranya mereka akan mampu melihat dunia. Hal ini sesuai dengan pernyataan Robert McKee (1999) dalam sebuah seminar bahwa "Storytelling is the most powerful way to put ideas into the world today."

Cerita sejarah, perlu memuat unsur intrinsik cerita, antara lain sebagai berikut. 


\section{Setting}

Di mana (tempat), kapan (waktu), dan dalam budaya mana cerita itu terjadi. Peristiwa sejarah terjadi pada desa atau kota tertentu, di dalam dan di luar rumah. Setting membantu pendengar untuk menemukan setting dalam memori, atau membentuk latar tergayut (dengan deskripsi pencerita). Setting disimpan dalam memori episodik, sebagaimana halnya peristiwa dan pengalaman (lihat Field, 2003).

Setting meliputi, setidaktidaknya, lokasi (lapangan, gunung, ditunjukkan dengan nama), waktu (kapan cerita terjadi), waktu historis (17 tahun lalu, tanggal 29 September1965), waktu musim (musim panas, musim hujan, salju), waktu seharihari (pagi atau sore hari), dan waktu cuaca (saat hujan turun dengan lebat).

\section{Charakter}

Berkisah tentang siapakah cerita tersebut, bagaimana sifat dan tabiatnya dalam menghadapi masalah. "Who's the story about?", merupakan pertanyaan yang diajukan untuk karakter. Apabila karakter tokoh yang baik untuk cerita anak adalah flat (hitamputih), karakter tokoh untuk cerita sejarah disarankan lebih riil. Artinya karakter cerita sejarah lebih bulat (round character), ada sifat baiknya, ada pula sifat buruknya.

Apabila cerita fiksi lebih menonjolkan pertentangan sifat tokoh dan tokohnya, maka cerita sejarah, umumnya, lebih fokus pada pencapaian perjuangan atau mengatasi rintangan. Tokoh tergambar sebagai pribadi yang kompleks (dan itulah yang menarik).

Karakter dapat digambarkan dengan tiga cara, yakni (1) menunjukkan atau mendeskripsikan penampilan tokoh: beranting sebelah, bertato, berjubah, bercaping, berkuda, berpakaian adat, berpakaian tentara, tinggi-besar-tegap, kurus tapi sehat, dan sebagainya, (2) mengoptimalkan dialog tokoh (karena asumsinya, bahasa menunjukkan kepribadian dan ciri seseorang): penggunaan jargon, slang, ciri fonemis (pelafalan, nada, irama), (3) menunjukkan atau menggambarkan perilaku tokoh: selalu tersenyum, suka membentak, tidak pernah tersenyum, berbicara sambil melotot, dan berkacak pinggang.

\section{Plot}

Menyajikan jalinan peristiwa, urutan peristiwa, "What's happening?" Plot juga menyajikan mengapa peristiwa terjadi. Plot adalah peristiwa-peristiwa naratif yang disusun dalam serangkaian waktu. Plot juga dapat didefinisikan sebagai peristiwaperistiwa narasi (cerita) yang penekanannya terletak pada hubungan kausalitas (Forster, 1966:93). Walaupun berisi urutan kejadian, tiap kejadian dalam plot dihubungkan secara sebab akibat, peristiwa yang satu menyebabkan 
peristiwa yang lain (Stanton, 1965:14).

Plot memiliki beberapa variasi. Plot yang dapat dipilih sebagai plot cerita sejarah adalah sebagai berikut.

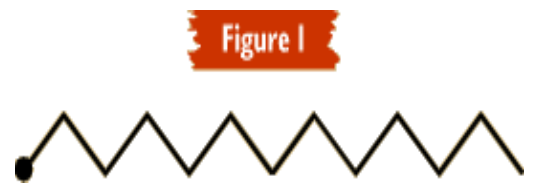

"Plot episodik" digunakan untuk menggambarkan peristiwa melalui serangkaian petualangan. Peristiwa muncul dan teratasi, begitu seterusnya hingga mirip kehidupan sehari-hari. Apa yang dialami tokoh tidak benar-benar keras. Rintangan kecil-kecil muncul lalu dapat teratasi hingga tidak terasa, kehidupan telah memakan banyak waktu.

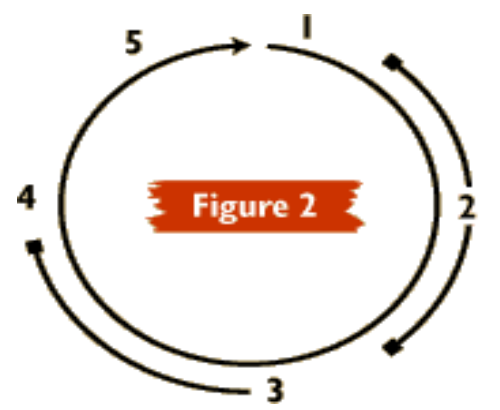

Plot yang biasa digunakan untuk kisah-kisah heroik. Autobiografi dapat diolah dengan plot "perjalanan hero" ini.

1) hero terpanggil untuk melaku-kan petualangan

2) perjalanan ke dunia asing, sang hero mengalami cobaan

3) cobaan sangat berat

4) berhasil dan memperoleh penghargaan
5) kembali ke keluarga (masyarakat)

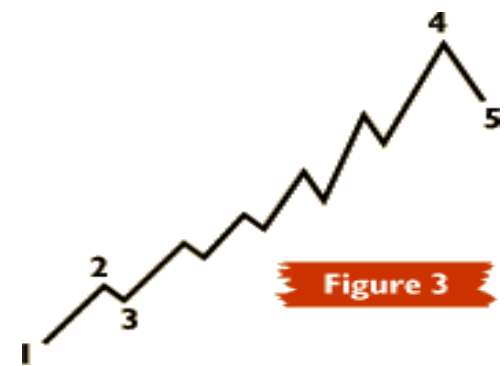

"Plot Gunung" sering digunakan dalam novel. Plot berisi struktur mini klimaks yang terus menanjak pada klimaks.

1) awal cerita, ketegangan mulai muncul

2) tokoh protagonis mengalami kesulitan, lalu sedikit menurun

3) tokoh dapat mengatasi masalah, lalu muncul masalah baru, terus hingga terulang dan terbangun bentuk yang semakin meninggi.

4) cerita mencapai klimaks. Tokoh mengalami puncak masalah (berhasil atau gagal)

5) muncul konklusi, muncul ketenangan.

\section{Figure 4}

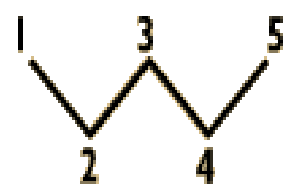

"Plot W" sering dijumpai pada novel, film.

1) Tokoh mengalami rintangan pertama

2) Kondisi tidak baik, tetapi tokoh dapat menangani rintangan pertama.

3) Tokoh mengalami rintangan kedua 
4) Penanganan rintangan kedua. Tokoh masih mampu mengalami rintangan kedua, mampu menangani bencana.

5) Tokoh kembali mengalami tantangan, dan cerita berakhir tragis.

\section{Backstory}

Backstory menurut Kimberly Appelcline (2008), "is the history behind the story, the past behind the settings, characters, and events brought to life on the page." Ini berarti, backstory berisi cerita tentang hal-hal yang diperlukan untuk memperjelas peristiwa (yang sedang, akan, dan telah diceritakan), menunjukkan kaitan karakter tertentu dengan masa lalunya atau menunjukkan peristiwa-peristiwa masa lalu yang terkait dan membangun plot. Mengapa tokoh begitu takut melihat api, misalnya, dapat dipilih sebagai alasan menghadirkan backstory. Pendek kata, pertanyaan, "What happened before, to create and inform this situation?", merupakan pertanyaan yang perlu dijawab (ditampilkan dalam cerita) agar cerita menjadi logis (menurut kriteria cerita itu sendiri).

Backstory dapat ditampilkan dengan berbagai cara, yakni narasi, deskripsi, dialog. Narasi dipilih apabila pencerita hendak mengisahkan sesuatu yang memerlukan flashback. Deskripsi dipilih untuk menggambarkan karakter fisik dan objek latar. Dialog dipilih apabila pencerita ingin menghadirkan dialog tentang keadaan atau meng- ungkapkan karakter tokoh dengan bahasa sendiri.

Jangan terlalu sering menghadirkan backstory, karena cerita akan kehilangan atensi dan kepaduan alur. Apabila terus menerus menghadirkan backstory, tidak mustahil Anda akan kehilangan detil dan pijakan cerita saat Anda masuk ke dalam backstory.

\section{Detail}

Mengacu pada hal-hal khusus atau detil-detil apa dan mana yang harus disajikan di hadapan penikmat cerita "Which specific things should your audience notice?". Detil, seperti halnya backstory, terkait dengan seluruh komponen cerita. Detil diberikan pada latar, peristiwa, dan komponen lain untuk membawa imajinasi pendengar. Seperti detil dalam novel, detil dalam cerita menunjukkan penghayatan dan pengetahuan penceritanya. Detil seperti bentuk rumah, warna, cara, ekspresi, dan emosi khas, dapat membawa pendengar ke setting atau imajinasi yang lebih kaya. Perlu diperhatikan, seberapa banyak detil yang dibutuhkan dan detil apa yang dibutuhkan.

\section{Bercerita dengan Sejarah}

Bercerita, di samping diakui sebagai metode pembelajaran bahasa dan seni berbahasa yang tertuateruji, juga diakui sebagai metode pembelajaran sejarah yang paling menarik dan persuasif. Sejarah yang 
disajikan dalam bentuk cerita memang memiliki resiko terdistorsi atau sebaliknya terinterpolasi, meskipun demikian efektivitasnya sulit ditandingi oleh metode lain.

Bercerita dengan materi sejarah, perlu diolah dengan prinsip-prinsip berikut.

1. Bercerita Interaktif

Bercerita cerita sejarah menuntut detil yang tepat. Validitas dilakukan, setidaktidaknya, terhadap unsur peristiwa, tokoh, dan latar.

Bercerita cerita sejarah menuntut interaksi aktif dengan pendengar sebagai salah satu upaya untuk mempertahankan detil dan mengontrol penyerapannya pada pendengar. Walaupun sangat sulit, karena sejarah mensyaratkan konsistensi detil alur, interaksi sesungguhnya dapat dimanfaatkan sebagai umpan balik, kontrol, selingan, dan filled pause apabila pencerita lupa.

Agar tidak mengganggu konsentrasi penikmat sejarah, interaksi sebaiknya tidak dilakukan sdalam porsi besar. Tidak ada pedoman pasti seberapa banyak interaksi dapat dilakukan, tetapi melalui pengalaman, pencerita dapat melakukan semacam "tes". Se-makin serius sebuah cerita, semakin sedikit interaksi terjadi. Frekuensi in-teraksi yang berlebih dapat memunculkan interpolasi tak terkendali.

2. Bercerita dengan Kata-kata

Bercerita dengan kata-kata mengandung arti, "hati-hati dengan kata-kata". Apabila cerita fiksi dapat mendatangkan efek tertentu (termasuk efek multiinterpretasi dan taksa makna), apalagi cerita sejarah yang menuntut interpretasi relatif sama. Penggunaan kata-kata, seperti verba aktif dan pasif, diksi (pilihan kata) sangat mempengaruhi makna peristiwa, peran dan karakter tokoh, serta akhirnya memengaruhi interpretasi.

"Gajah Mada memberi titah (bukan diberi titah). Hayam wuruk seketika murka (bukan mencaci maki). Insinyur Soekarno takzim (bukan takut). Letjen Soeharto melaksanakan perintah (bukan menginginkan perintah)".

Oleh karena menggunakan kata-kata, cerita harus dilengkapi dengan paralinguistik seperti vokalisasi, gerak tubuh, gesture, dan mimik sebagai pendukung makna (bukan justru menghancurkannya karena pralinguistik yang tidak sesuai).

3. Bercerita Berarti Menyajikan Cerita

Bercerita bukan memberikan informasi. Bercerita adalah menyajikan cerita. Oleh karena menyajikan, bercerita merupakan komunikasi high contex. Walaupun telah dipersiapkan dengan matang, bercerita (termasuk cerita sejarah) tetap memperhatikan konteks yang dihadapi: siapa pendengarnya, bagaimana kondisi mereka. "Interaksi" batin antara pencerita dengan penikmat/pendengar harus terjadi, sehingga cerita 
dimulai dari konteks yang dihadapi.

Bercerita menyajikan cerita yang merangsang pencerita untuk melakukan terobosan-terobosan kreatif sekiranya konteks tidak sinkron dengan harapan. Terobosan yang dapat diambil antara lain, penataan tempat duduk, menyeleksi sarana kebahasaan (kata, pelafalan, struktur, dan kompleksitasnya), menekankan deskripsi, serta menggunakan unsur cerita tak cerita.

4. Bercerita dengan Aktivasi Imajinasi

Mendengarkan cerita berbeda dengan menonton cerita. Ketika membaca novel "Ayat-ayat Cinta" pembaca mengaktivasi imajinasi, menyimpannya secara merdeka dan mendalam dalam dirinya. Tetapi begitu menonton filmya, imajinasi mereka bertolak (berpindah menuju) imajinasi terbimbing. Flat Maria dan flat Fahri terimajinasi secara berbeda oleh pembaca dan penonton film.

Bagaimana halnya dengan cerita sejarah? Apakah aktivasi imajinasi dapat dibenarkan? Sepanjang yang dimaksud cerita sejarah bukan menyajikan dokumentasi/informasi yang telah terjadi, imajinasi tetap menjadi hak prerogatif pendengar. Tidak perlu merisaukan efek imajinasi, karena kebebasannya tetap dibersyaratkan oleh skema dan pengalamannya. Artinya, imajinasi terhadap cerita akan terkoreksi oleh perjalanan waktu.

Penguatan imajinasi (untuk tujuan penghayatan dan pe- nguatan storasi) sangat baik dilakukan dengan bantuan musik, nada-irama berbicara, dan berbagai bentuk ekspresi.

5. Pemanfaatan Unsur Cerita Tak Cerita

Cerita sejarah kaya akan artefak dan dokumen bukti seperti foto-foto, gambar, relief, patung, diorama. Unsur tersebut disebut unsur cerita tak cerita (atau unsur tak cerita). Unsur tak cerita sangat membantu pendengar (terutama anak-anak) untuk memahami isi cerita (sejarah). Dengan foto, pendengar akan memperoleh gambaran sosok tokoh, latar tempat dan budaya pada masa lalu. Unsur tak cerita sedapat mungkin dimanfaatkan, seperti bercerita di candi (dengan mengoptimalkan gambar-gambar pada relief), bercerita di museum dengan bantuan diorama, dan bercerita di kelas dengan slide, gambar, foto, dan suara asli tokoh (seperti pidato Soekarno dan Bung Tomo).

Orang dewasa dapat memilih dan menilai cerita, serta mengambil hikmahnya. Sayang-nya, tidak demikian halnya dengan anak. Tahap perkem-bangan anak didik dalam berbagai aspek (terutama kognisi dan moral), membatasi mereka untuk memilih mana cerita yang baik dan mana cerita yang tidak baik, membatasi mereka untuk menilai mana cerita yang benar dan mana yang tidak. Anak melahap semua cerita yang mereka sukai, mes-kipun cerita itu buruk, dan meninggalkan cerita yang tidak mereka sukai 
meskipun cerita itu baik. Oleh karena itu, sajikan cerita yang baik dengan cara yang baik, agar yang baik itu disukai anak-anak kita.

\section{Strategi Bercerita}

Bercerita memerlukan strategi. Strategi dilakukan dalam tiga tahap, yakni tahap persiapan, penyajian, dan evaluasi. Strategi pada tahap persiapan awal, diperinci menjadi sub-sub berikut ini:
Dramatic Structure

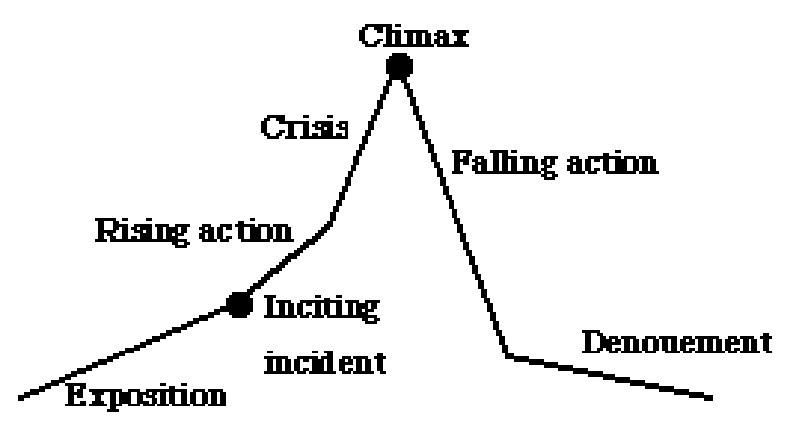

\section{Interaction}

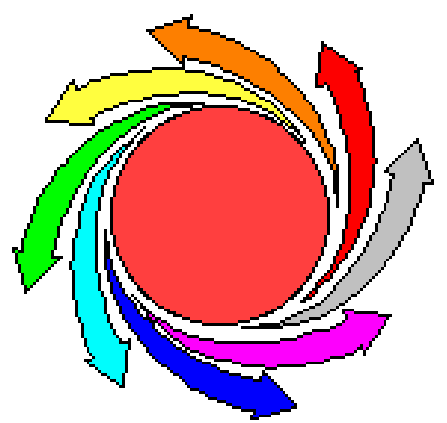

\begin{tabular}{|c|c|}
\hline 1. Select your story & $\begin{array}{l}\text { Pemilihan cerita didasarkan pada: } \\
\text { 1. tujuan bercerita } \\
\text { 2. karakteristik partisipan/penikmat cerita (usia) } \\
\text { 3. karakter sejarah (tingkat kekompleksan, cakupan } \\
\text { keluasan) } \\
\text { Untuk anak-anak, pilih cerita yang bertema baik, heroik, } \\
\text { tidak berpotensi sara, tidak terkesan subjektif golongan, } \\
\text { mudah dipahami, dan membangkitkan semangat. Cerita } \\
\text { sejarah tokoh (autobiografi) sangat cocok untuk memb- } \\
\text { angkitkan visi ke depan anak-anak (lihat Hatersley, } \\
\text { 1997). } \\
\text { Pemilihan cerita dapat dilakukan oleh anak-anak. }\end{array}$ \\
\hline $\begin{array}{l}\text { 2. Learn the plot } \\
\text { and characters }\end{array}$ & $\begin{array}{l}\text { Pelajari setiap peristiwa yang ada dalam cerita, urutan, } \\
\text { dan jalinannya sehingga jelas terlihat unsur-unsur plot- } \\
\text { nya. Konsentrasi plot (peristiwa, alur, dan jalinan) sangat } \\
\text { kuat dalam cerita sejarah. } \\
\text { Tokoh yang diceritakan memiliki nama, sifat, lengkap } \\
\text { dengan kelebihan dan kelemahan. } \\
\text { Cerita sejarah memiliki kelebihan dalam hal plot dan } \\
\text { karakter. Tokoh sejarah lebih bulat atau round character } \\
\text { daripada tokoh fiksi pada umumnya. }\end{array}$ \\
\hline
\end{tabular}


3. Visualize the plot Bayangkan, imajinasikan, dan tata dalam pikiran semua and characters peristiwa, alur, dan jalinannya dalam pikiran. Camkan in your mind bagaimana sifat, peran para tokoh cerita (utama, tambahan) dan peristiwa. Tunjukkan tokoh hero yang mengemban cerita secara proporsional.

Bagi pendidik, bercerita dengan materi sejarah, mutlak "hafal di luar kepala" semua peristiwa, latar tempat, dan peran tokoh dalam peristiwa tersebut.

4. Rehearse the Berlatih dengan suara (seperti berlatih di depan kaca) story aloud sangat penting. Jangan lewatkan kesempatan berlatih. several times Berlatih berfungsi menguatkan memori, mencegah peluruhan detil, dan membantu menguatkan kembali jalinan cerita. Berlatih juga mampu mengeksplorasi unsur-unsur cerita sehingga tampil lebih baik. Berlatih mencegah lupa dan meminimalkan terjadinya kemungkinan interpolasi.

5. Add detail to the Pemberian detil perlu dilakukan apabila pencerita plot and characters merasa garis besar cerita tidak jelas bagi calon pendengar. Detil mungkin berisi fakta (tinggi badan, warna kulit) tapi mungkin berisi interpretasi pencerita terhadap sumber (sangat marah: suara keras, mata melotot, menggigit bibir, giginya gemeretak). Lakukan pendetilan terhadap tokoh, latar, dan peristiwa. Pencerita dapat mengamati foto yang diabadikan dalam buku-buku sejarah dan unsur tak cerita yang lain.

6. Own the story Sebagus apa pun cerita (sejarah) yang dipilih, perlike it is your formansi bercerita mengharuskan internalisasi sehingga own! cerita merasuk dalam diri pencerita. Bercerita tentang Diponegoro, Gajah Mada, atau perang kemerdekaan akan lebih menarik apabila pencerita benar-benar menghayati jalan cerita dan tokoh-tokohnya. Berceritalah seolah-olah Anda (sebagai pencerita) ikut mengalami atau menyaksikan kejadian yang diceritakan.Tahap ini menguatkan rasa percaya diri pencerita.

Strategi pada tahap penyajian dapat dilakukan dengan berbagai cara. Strategi ini sedikit berbeda dengan strategi bercerita dengan materi fiksi (dongeng, cerpen) maupun bentuk lain (mite dan legenda). Strategi yang dimaksud adalah sebagai berikut:

1. Deskripsi setting 1. Mulai exposition dengan deskripsi latar yang kuat. dan karakter Deskripsi yang kuat sangat ditentukan eksplorasi pada tahap awal. 


\begin{tabular}{|l|l|}
\hline 2. Optimalkan & $\begin{array}{l}\text { 1. Dialog untuk cerita sejarah perlu dibatasi agar tidak } \\
\text { terlalu banyak unsur interpolasi. }\end{array}$ \\
& $\begin{array}{l}\text { 2. Dialog dibangun dengan warna/karakter suara, nada, } \\
\text { irama, volume apabila mampu. Gunakan alat peraga } \\
\text { apabila memerlukan (jika suara tidak mampu } \\
\text { memiku beban dialog). Strategi lain adalah } \\
\text { menggunakan kalimat tidak langsung sebagai bingkai } \\
\text { dialog. } \\
\text { Pengoptimalan dialog memiliki banyak manfaat (lihat } \\
\text { Musfiroh (2008) }\end{array}$ \\
\hline 3. Menyematkan & $\begin{array}{l}\text { 1. Interaksi dapat dilakukan dengan tanya jawab untuk } \\
\text { mengembalikan konsentrasi atau evaluasi proses. }\end{array}$ \\
Interaksi & $\begin{array}{l}\text { 2. Interaksi humor hanya dapat dilakukan apabila cerita } \\
\text { memungkinkan. Humor yang tepat merangsang sikap } \\
\text { toleran (Shapiro, 1999). }\end{array}$ \\
3. Interaksi hanya dilakukan pada saat diperlukan, tidak \\
berlebihan.
\end{tabular}


Strategi pada tahap akhir dilakukan setelah cerita selesai diceritakan. Strategi ini berlaku bagi semua pendengar, apabila pendengar adalah peserta didik-. Strategi ini terkait dengan evaluasi dari bentuk yang paling dasar yakni retelling hingga ke bentuk yang paling kompleks yakni produksi.

Langkah-langkah yang dapat dilakukan untuk tahap akhir ini meliputi merangkum cerita, menjawab pertanyaan, internalisasi dan refleksi, serta produksi. Pencerita dapat memilih satu atau beberapa kegiatan sesuai waktu yang tersedia. Tahap produksi dapat dilakukan apabila kegiatan bercerita sudah mulai diminati dan anak memiliki perbendaharaan cerita yang relatif banyak. Meskipun demikian, pada beberapa anak yang memiliki kecenderungan senang berekspresi, kegiatan produksi akan muncul lebih awal.

\begin{tabular}{|c|c|}
\hline $\begin{array}{l}\text { 1. Merangkum } \\
\text { Cerita }\end{array}$ & $\begin{array}{l}\text { 1. Merangkum cerita dilakukan oleh pendengar untuk } \\
\text { "mengukur" seberapa jauh pendengar dapat mencerna } \\
\text { cerita. Fokuskan rangkuman pada unsur peristiwa, } \\
\text { latar, dan tokoh. Pendengar boleh menggunakan } \\
\text { bahasa mereka sendiri. } \\
\text { 2. Merangkum dapat dilakukan secara individu maupun } \\
\text { kelompok, lisan maupun tertulis. } \\
\text { 3. Rangkuman dapat dibuat dalam bentuk mindmap. } \\
\text { Pada anak-anak, merangkum perlu dibantu oleh guru } \\
\text { (bantuan yang bernilai scaffolding) bukan alih tugas anak } \\
\text { ke guru. }\end{array}$ \\
\hline $\begin{array}{l}\text { 4. Menjawab } \\
\text { Pertanyaan }\end{array}$ & $\begin{array}{l}\text { 1. Beri kesempatan anak bertanya pada Anda atau } \\
\text { sebaliknya menjawab. } \\
\text { 2. Beri kesempatan anak menjawab pertanyaan Anda } \\
\text { dan melakukan balikan. }\end{array}$ \\
\hline $\begin{array}{l}\text { 3. Internalis } \\
\text { Refleksi }\end{array}$ & $\begin{array}{l}\text { 1. Anak perlu waktu untuk memahami, merenungkan isi } \\
\text { cerita, dan mengambil hikmah apa yang dapat diserap } \\
\text { darinya. } \\
\text { 2. Tuntun pendengar (terutama jika mereka adalah } \\
\text { peserta didik) untuk merefleksi cerita tersebut. } \\
\text { Tuntun anak membuat usulan hal apa yang perlu } \\
\text { ditindaklanjuti setelah menyimak cerita. Beri } \\
\text { kesematan anak menghubungkan cerita sejarah Anda } \\
\text { dengan kondisi pada masa kini. }\end{array}$ \\
\hline 3. Produksi & $\begin{array}{l}\text { Produksi adalah hasil tertinggi yang dibidik oleh strategi } \\
\text { ini. Produksi berupa cerita, cerpen, laporan menyimak, } \\
\text { skenario, atau cerita ulang dalam bentuk lisan }\end{array}$ \\
\hline
\end{tabular}


(retelling).Anak yang suka menggambar, mungkin lebih suka membuat gambar atau komik.

\section{Sejarah sebagai Kontra Cerita}

Cerita sejarah memilki peluang besar untuk menarik perhatian anak. Saat ini, kebutuhan anak akan cerita mulai diisi oleh sinetron dan cerita lain yang cenderung tidak mendidik. Seperti dinyatakan dr. Boyke, anakanak mulai mengonsumsi cerita porno. Cerita jenis ini, sangat mempengaruhi sikap dan gaya hidup anak dan remaja Indonesia. Berbagai tindak kriminal terjadi sebagai akibat dari konsumsi cerita tak mendidik tersebut.

Di lain sisi, sejarah dan sastra tidak diminati oleh sebagian peserta didik karena dua alasan. Pertama, sejarah disajikan melalui ceramah sehingga tidak menarik. Kedua, sastra lebih banyak diisi dengan instruksi sehingga kebutuhan akan modelling tidak terpenuhi. Akibatnya, sejarah dan sastra (Inklusif dalam bahasa Indoensia) menjadi mata pelajaran yang tidak diperhitungkan.

Pengemasan sejarah dalam bentuk cerita (dan sejenisnya), pada hemat saya, dapat menjadi alternatif pembelajaran. Oleh karena sejarah memiliki materi yang demikian beragam, cerita sejarah -saya yakinakan banyak menyedot perhatian anak didik. "Kisah Para Nabi", "Laksamana Cheng-Ho", "Kerajaankerajaan di Indonesia", "Gajah Mada" merupakan contoh-contoh cerita sejarah yang sangat digemari anakanak. Penyajian cerita sejarah (termasuk biografi) mampu merangsang minat baca anak, sebagaimana buku-buku Harry Potternya J.K. Rowling.

Fenomena "Ayat-ayat Cinta", Harry Potter, sinetron, dan ceritacerita porno pada anak, remaja kita menunjukkan bahwa kerinduan mereka pada cerita tidak pernah luntur. Anak-anak sangat menyukai guru mata pelajaran sejarah, agama, dan bahasa yang pandai dan sering bercerita. Sebaliknya, ketiga mata pelajaran di atas terkesan membosankan di tangan guru yang serba direktif dan penuh ceramah. Hal ini berarti, mengembalikan konstruk sejarah-agama-sastra ke dalam bentuk cerita perlu (untuk tidak terkesan mutlak) dilakukan.

Para guru sejarah mungkin akan bertanya menggugat, "Dapatkan cerita mengantarkan sejarah sebagai kontra cerita yang tidak mendidik?" dan "Bagaimana melakukannya". Dalam kesempatan ini, saya menjawab, “Mengapa Tidak?" Sejarah memiliki beberapa kelebihan dibandingkan "cerita" di atas.

(1) Sinetron dan cerita erotis-porno memang mengundang rasa ingin tahu, tapi keduanya tidak memiliki kedalaman. Penikmatnya akan cepat bosan dan beralih ke cerita lain. Sebaliknya, sejarah memiliki nilai kedalaman yang semakin digali akan semakin menguatkan wawasan. 
(2) Sinetron dan cerita erotis-porno menstimulasi dorongan seksual, yang pada diri manusia terkesan menarik dan muncul secara alamiah. Meskipun demikian, cerita semacam itu tidak menstimulasi aspek moral, sosial, dan logika. Sebaliknya, sejarah memiliki kemampuan merangsang aspek emosi, moral, sosial, dan logika. Semakin banyak memahami sejarah, semakin banyak manusia belajar. Cerita biografi, bahkan memiliki pesona yang sangat kuat untuk melecut semangat pembaca dan pendengarnya.

(3) Sinetron dan cerita erotis-porno memiliki setting yang dekat dengan lingkungan nyata dan menarik perhatian. Meskipun demikian, kedua cerita tersebut tidak memiliki kualitas budaya yang tinggi. Sebaliknya, sejarah memiliki kekayaan budaya yang tidak pernah habis untuk dieksplorasi. Unsur cerita tak cerita merupakan kekayaan sejarah yang benar-benar bernilai dan berdaya tarik.

(4) Sinetron dan cerita erotis-porno dapat dikembangkan ke dalam cerita yang lebih variatif. Keunggulan ini pun dimiliki sejarah. Kemunculan fiksi-fiksi sejarah dan variasi sejarah menunjukkan bahwa sejarah dapat berkembang dan dikembangkan. Cerita dengan kandungan sejarah (seberapa pun kadar kebenarannya), seperti Gajah Mada (2004), Candi Murca I, Ken Arok Hantu Padang Karautan (2006) karya
Langit Krisna Hariadi merupakan contoh fiksi-sejarah (yang laris manis di pasaran).

\section{Penutup}

Ada berbagai strategi bercerita sejarah. Paparan di atas hanyalah sebagian bentuk. Strategi terbaik akan ditemukan ketika kita telah berhadapan langsung dengan penikmat cerita. Sebagai pencerita, kita memiliki kewajiban mendudukkan penikmat kita sebagai "konsumen". Oleh karena itu, kita wajib memberikan yang terbaik, walaupun mereka adalah anak didik kita.

Dengan memberikan cerita sejarah yang baik, kita telah memberikan virus baik pada anak-anak untuk melawan virus jahat dari cerita lain. Anak-anak mungkin akan meniru kata-kata atau perilaku dari cerita yang tidak baik, tetapi mereka akan belajar dari cerita yang mendidik. Mengapa cerita sejarah mampu menjadi virus baik atau anti virus? Karena kemampuan bercerita, termasuk bercerita sejarah, dapat dipandang sebagai kemampuan yang multifaktor. Kegiatan bercerita terkait dengan sastra, sejarah, pengalaman, pandangan hidup, adat istiadat, kepercayaan, politik, citacita, dan kegiatan lain di sekitarnya (lihat Dipodjojo, 1986). 


\section{Daftar Pustaka}

Baker, A. \& Greene, E. 1977. "Storytelling: Art and Technique". New York: Bowker.

Boje, M. David. 2002. "Notes on the Strategic Stories fad".

Dipodjojo, Asdi S. 1986. Kesusasteraan Indonesia pada Zaman Pengaruh Islam. Yogyakarta: Penerbit Lukman.

Field, John. 2003. Psycholinguistics. New York: Routledge Taylor \& Francis Group.

Forest, Heather. 2007. Inside Story: An Arts-Based Exploration of the Creative Process of The Storyteller as Leader. Disertasi Antioch University (versi web).

Forster, E.M. 1966. Aspect of The Novel. England: Penguin Book.

Hattersley, Michael. 1997. "The Managerial Art of Telling a Story." Harvard Management Update, January.

McWilliams, Barry. 2003. "Choosing Story Teaching Methods". http://www.eldrbarry.net.

Musfiroh, Tadkiroatun. 2008. Memilih, Menyusun, dan Menyajikan Cerita untuk Anak Usia Dini. Yogyakarta: Tiara Wacana.

Shapiro, Lawrence E. 1999. Mengajarkan Emotional Intelligence pada Anak. (alih bahasa: Alex Tri Kantjono). Jakarta: Gramedia.

Stanton, Robert. 1973. How to Analyze Fiction. New York: Monarch Press.

Teeuw, A. 1988. Sastra dan Ilmu Sastra: Pengantar Teori Sastra.
Jakarta: Pustaka Jaya - Guru Mukti Pasaka. 